\title{
KONTRIBUSI PENYELENGGARAAN SIARAN TELEVISI EDUKASI (TVE) TERHADAP PENUNTASAN WAJIB BELAJAR PENDIDIKAN DASAR 9 TAHUN
}

Oleh : Rini Susanti*

\section{Abstrak}

Sejak berdirinya 3 tahun yang lalu, banyak hal telah dilakukan dalam penyelenggaraannya. Berbagai kalangan pemerhati pendidikan mulai mempertanyakan kontribusi siaran TVE terhadap penuntasan Wajar Dikdas 9 Tahun. Penelitian ini dilaksanakan di SMP yang tersebar di 28 Propinsi di Indonesia pada bulan Desember tahun 2006. Metode yang digunakan adalah metoda survei. Populasinya adalah siswa-siswa SMP dan guru yang tersebar di sekolah perintisan dari 28 propinsi. Hasil analisis menunjukkan bahwa sebagian besar siswa belum memanfaatkan siaran TVE secara efektif. Sedangkan guru telah memanfaatkan siaran TVE cukup efektif. Kontribusi siaran TVE ditunjukkan pada setiap peningkatan satu unit skor efektivitas pemanfaatan siaran TVE pada konstanta -5,69 menghasilkan 0,124 peningkatan hasil belajar siswa. Kekuatan hubungan antara efektivitas pemanfaatan siaran TVE dengan hasil belajar siswa berdasarkan uji signifikansi koefisien korelasi ditunjukkan oleh korelasi $r=0,685$ dengan persamaan regresi $v=-5,69+$ $0,124 X$. Hal ini berarti setiap peningkatan satu unit skor efektivitas pemanfaatan siaran TVE pada konstanta -5,69, menghasilkan 0,124 peningkatan hasil belajar siswa, atau dengan perkataan lain, semakin tinggi efektivitas pemanfaatan siaran TVE, maka semakin tinggi skor hasil belajar siswa. Sebaliknya, semakin rendah efektivitas pemanfaatan siaran TVE, maka semakin rendah skor hasil belajar siswa.

Kata kunci : Kontribusi, Efektivitas, Siaran Televisi Edukasi

*) Dra. Rini Susanti, M.Pd. adalah staf Bidang Teknologi Komunikasi Pustekkom Depdiknas 


\section{PENDAHULUAN}

Pustekkom Depdiknas sejak tahun 2004 kembali menggunakan media TV untuk membantu siswa dan guru dalam proses belajar mengajar. Penyelenggaraan siaran televisi pendidikan melalui Televisi Edukasi (TVE) ini bertujuan mendukung program Depdiknas dalam pemerataan kesempatan memperoleh akses dan peningkatan mutu pendidikan serta menuntaskan wajib belajar 9 tahun (Wajar Dikdas 9 Tahun).

Penuntasan Wajar Dikdas 9 Tahun direncanakan akan selesai pada tahun 2008/2009. Tujuan utama dilaksanakannya gerakan nasional penuntasan Wajar Dikdas 9 Tahun di antaranya adalah meningkatkan angka partisipasi anak untuk masuk sekolah SMP/ MTs terutama di daerah yang jumlah anak tidak bersekolah SMP/ MTs masih tinggi. Penuntasan Wajar Dikdas 9 Tahun merupakan program bersama antara pemerintah, swasta, dan lembagalembaga sosial serta masyarakat.

Sementara itu, Indonesia yang memiliki wilayah yang luas dan terdiri dari 13 ribuan pulau, sampai sekarang masih mengalami hambatan dalam memeratakan pendidikan dan peningkatan mutu pendidikan. Melihat kondisi psikologis dan geografis Indonesia yang demikian ini, diperlukan adanya suatu terobosan dan strategi baru untuk mengatasi masalah yang kompleks dalam penuntasan Wajar Dikdas 9 Tahun. Saat ini, perkembangan teknologi informasi dan komunikasi demikian pesatnya sehingga perlu dimanfaatkan secara maksimal untuk membantu penuntasan Wajar Dikdas 9 Tahun.

Teknologi informasi dan komunikasi yang paling populer di masyarakat saat ini salah satunya adalah televisi. Hampir sebagian besar masyarakat Indonesia mempunyai televisi. Bahkan sebagian besar dari kehidupan manusia ada di depan televisi. Media televisi telah terbukti memiliki kemampuan yang efektif (penetrasi lebih dari $70 \%$ ) untuk menyampaikan informasi, hiburan, dan pendidikan. 
Potensi televisi untuk pendidikan tidak diragukan lagi. Pengalaman dari negara lain, baik negara maju maupun negara berkembang yang telah memanfaatkan media televisi untuk pendidikan. Cina mempunyai 3 (tiga) saluran (channels) siaran televisi untuk pendidikan dan masing-masing televisi menyiarkan selama 10 (sepuluh) jam setiap harinya sehingga rakyat Cina mendapatkan siaran televisi tentang pendidikan sebanyak 30 jam. Di Thailand, Malaysia, dan masih banyak lagi negara lain telah mempunyai siaran televisi untuk pendidikan dengan jumlah saluran dan lama siaran yang bervariasi.

Penyelenggaraan siaran TVE sangat membantu masyarakat memperoleh akses pendidikan. Sejauh ini, siaran TVE berfungsi sebagai media pembelajaran bagi peserta didik pada jenjang pendidikan dasar dan menengah, termasuk mereka yang tinggal di daerah terpencil. Dalam rangka pemerataan kesempatan dan peningkatan mutu pendidikan serta membantu penuntasan Wajar Dikdas 9 Tahun, siaran TVE sejak berdirinya sampai saat ini telah berlangsung selama lebih kurang 3 tahun. Banyak hal telah dilakukan dalam penyelenggarannya.

Berbagai kalangan pemerhati pendidikan mulai mempertanyakan kontribusi siaran TVE terhadap penuntasan Wajar Dikdas 9 Tahun. Beberapa hal yang ingin diketahui masyarakat adalah bagaimana efektivitas pemanfaatan siaran TVE dan berapa besar peningkatan kualitas yang akan dicapai.

\section{EFEKTIVITAS PEMANFAATAN SIARAN TVE}

Sejalan dengan tujuan diselenggarakannya siaran TVE, Pustekkom telah merintis lokasi pemanfaatan siaran di SMP/MTs yang tersebar di kabupaten/kota di Indonesia. Sekolah-sekolah perintisan tersebut dilengkapi dengan peralatan untuk memanfaatkan siaran TVE berupa pesawat TV, Parabola, DVD Player, dan Genset. Dalam rangka memperoleh data dan informasi tentang efektivitas pemanfaatan siaran TVE di sekolah-sekolah perintisan tersebut, Pustekkom telah melakukan penelitian. Hasil penelitian ini 
selanjutnya akan dijadikan sebagai salah satu masukan terhadap penyempurnaan pelaksanaan kebijakan/program Pustekkom tentang saiaran TVE.

Suatu sistem dinyatakan efektif apabila proses kerja yang dilakukannya mampu memberikan efek atau pengaruh dan tepat guna atau membawa hasil serta mencapai sasaran yang diinginkan ketika diterapkan. Drucker (1994;45-46) berpendapat bahwa yang dimaksud dengan efektif adalah upaya menjalankan pekerjaan dengan benar. Senada dengan pendapat tersebut Barto dan Martin $(1991 ; 20)$ mengemukakan bahwa sasaran efektivitas adalah harus benar dan bisa dicapai. Howard (2001) menjelaskan bahwa efektivitas adalah suatu keadaan di mana peralatan, metode, dan sumber daya digunakan dengan cara yang tepat guna mencapai tujuan yang diinginkan.

Berdasarkan pendapat para ahli di atas dapat disimpulkan bahwa secara konseptual, efektivitas merupakan taraf tercapainya suatu tujuan atau sasaran yang ditetapkan yang dilaksanakan dengan berdaya guna. Efektivitas pemanfaatan siaran TVE merupakan stimulus-stimulus yang mampu merangsang mekanisme reseptif peserta didik. Banyak sedikitnya stimulus yang menyertai aktivitas belajar siswa ditinjau dari taraf efektivitas pemanfaatan siaran TVE yang menunjang aktivitas belajar siswa.

Sedangkan secara operasional, efektivitas pemanfaatan siaran TVE didefinisikan sebagai skor yang diperoleh setelah responden menjawab keusioner efektivitas pemanfaatan siaran TVE dengan menggunakan skala Likert. Efektivitas pemanfaatan siaran TVE diukur melalui indikator: (1) kondisi peralatan penerima siaran, kelengkapan dan infrastruktur pendukung, (2) tercapainya pelaksanaan pemanfaatan yang meliputi pengelolaan/pengaturan tempat, jadwal dan strategi yang sesuai dengan sasaran yang ditetapkan, (3) pemanfaatan siaran TVE yang meliputi materi, metoda dan optimalisasi kualitas SDM dengan tepat sesuai dengan tujuan yang diinginkan. 


\section{Tempat dan Waktu Penelitian}

Penelitian dilaksanakan di SMP yang tersebar di 28 propinsi di Indonesia pada bulan Desember tahun 2006.

\section{Metode Penelitian dan Teknik Pengambilan Sampel}

Metoda yang digunakan penelitian ini adalah metoda survei. Teknik menganalisis data digunakan statistik.

Populasi dalam penelitian ini adalah siswa-siswa SMP, guru dan kepala sekolah yang tersebar di sekolah perintisan dari 28 propinsi. Teknik pengambilan sampel, yang digunakan sekolah multistage random sample yakni sampling acak yang dilakukan berdasarkan gugus bertahap. Teknik pengambilan sampel ini sesuai dengan pendapat Notoatmodjo (2002;87-88) dan Kerlinger (1990;207) yang menyatakan bahwa pelaksanaan pengambilan sampel dilakukan dengan cara membagi wilayah populasi ke dalam sub-sub populasi, dan tiap-tiap sub populasi dibagi ke dalam bagian-bagian yang lebih kecil, dan seterusnya.

Sedangkan untuk menentukan ukuran sampel yang representatif mewakili populasi dengan tingkat kepercayaan 95\% diambil berdasarkan tabel Krejcie dan Morgan (Sugiyono, 2001; 11-12) sehingga diperoleh ukuran sampel yang diperlukan tergambar pada teknik pengambilan sampel berikut ini:

- Stage I : Mengambil secara random 13 Propinsi sebagai sampel yang terdiri dari $32 \mathrm{Kab} / \mathrm{Kota}$ dari 28 Propinsi.

- Stage II : Mengambil secara random $21 \mathrm{Kab} / \mathrm{Kota}$ sebagai sampel yang terdiri dari 83 sekolah dari $32 \mathrm{Kab} /$ Kota.

- Stage III : Dari 83 sekolah, dicari sampelnya berdasarkan tabel Krejcie dan Morgan, sehingga diperoleh 68 sekolah.

Selanjutnya untuk memperoleh data empirik tentang efektivitas pemanfaatan serta kondisi peralatan siaran TVE, dipilih secara random 10 siswa, 10 guru dan seorang kepala sekolah untuk 
masing-masing sekolah sebagai responden penelitian.

\section{Instrumen}

Untuk memperoleh data empirik tentang kompetensi siswa dengan ruang lingkup materi siaran TVE, masing-masing reponden/sumber data dijaring melalui tes bentuk pilihan ganda yang instrumennya disusun oleh Pustekom. Instrumen yang digunakan untuk mengukur hasil belajar siswa adalah tes berbentuk pilihan ganda yang terdiri dari 30 butir, Jawaban yang benar diberi skor satu dan jawaban yang salah diberi skor nol. Dengan demikian, rentang skor teoritik skala hasil belajar siswa adalah 0 sampai 30 .

Instrumen yang digunakan untuk mengukur efektivitas pemanfaatan siaran TVE dengan responden siswa adalah kuesioner yang terdiri dari 54 butir pernyataan. Dengan demikian, rentang skor teoritik skala efektivitas pemanfaatan siaran TVE dengan responden siswa adalah 54 sampai 270 .

Instrumen yang digunakan untuk mengukur efektivitas pemanfaatan siaran TVE dengan responden guru adalah koesioner yang terdiri dari 63 butir. Dengan demikian, rentang skor teoritik skala efektivitas pemanfaatan sisran TVE degan responden guru adalah 63 sampai 315.

Skala yang digunakan adalah model skala Likert dengan rentang angka satu hingga lima. Respon dari responden dinyatakan dalam bentuk pilihan: SL, SR, JR, SJR dan TP dengan setiap pilihan jawaban dieri bobot skor berturut-turut sebagai berikut: 1, 2, 3, 4, dan 5 .

\section{Teknik Analisis Data Penelitian}

Dari data yang terkumpul dianalisis dengan menggunakan "Descriptive Statistics dan Inferential Statistic".

Untuk lebih memberikan gambaran yang lebih akurat terhadap data perolehan efektivitas pemanfaatan siaran TVE dan data hasil belajar matematika siswa, analisis "Descriptive Statistics" dihitung dengan menggunakan bantuan program komputer SPSS 10.0 for windows. 
Sebelum data yang terkumpul dianalisis lebih lanjut, terlebih dahulu dilakukan pemeriksaan keabsahan sampel melalui validasi interrater.

\section{Hasil Penelitian}

\section{Skor Hasil Belajar Siswa dengan Responden Siswa}

Untuk menyusun distribusi frekuensi dari perolehan skor hasil belajar siswa dapat dilakukan antara lain dengan menggunakan aturan Sturges (Sudjana, 1996;47). Dari skor data variabel hasil belajar siswa diperoleh skor minimum yaitu 5 , sedangkan skor maksimum 29, sehingga rentang skor hasil belajar siswa adalah 24.

Dengan menggunakan aturan Sturgess dan dengan jumlah 680 responden, maka diperoleh banyak kelas interval 9 , sedangkan panjang kelas interval 3 (hasil pembulatan berdasarkan syarat yaitu, p.i ${ }^{3} R+1$ ). Distribusi interval kelas, frekuensi absolut, frekuensi relatif, dan frekuensi kumulatif skor hasil belajar siswa. disajikan pada tabel 1 berikut ini (Kaplan, 1987;26-27).

Tabel1. Distribusi Interval Kelas, Frekuensi Absolut, Frekuensi Relatif, dan Frekuensi Kumulatif Skor Hasil Belajar Siswa.

\begin{tabular}{|c|c|c|c|c|}
\hline No. & Interval Kelas & $\begin{array}{c}\text { Frekuensi } \\
\text { Absolut }\end{array}$ & $\begin{array}{c}\text { Frekuensi } \\
\text { Relatif Naik } \\
\text { dalam }(\%)\end{array}$ & $\begin{array}{c}\text { Frekuensi } \\
\text { Kumulatif dalam } \\
(\%)\end{array}$ \\
\hline 1 & $5-7$ & 6 & 0,882 & 0,882 \\
\hline 2 & $8-10$ & 27 & 3,971 & 4,853 \\
\hline 3 & $11-13$ & 44 & 6,471 & 11,324 \\
\hline 4 & $14-16$ & 152 & 22,353 & 33,676 \\
\hline 5 & $17-19$ & 149 & 21,912 & 55,588 \\
\hline 6 & $20-12$ & 113 & 16,618 & 72,206 \\
\hline 7 & $23-25$ & 116 & 17,059 & 89,265 \\
\hline 8 & $26-28$ & 68 & 10,000 & 99,265 \\
\hline 9 & $29-31$ & 5 & 0,735 & 100,00 \\
\hline
\end{tabular}

Dari distribusi frekuensi di atas dapat diketahui bahwa 149 $(21,912 \%)$ responden berada pada kelompok rata-rata, sedangkan $229(33,676 \%)$ responden berada di bawah kelompok rata-rata, dan $302(44,412 \%)$ responden berada di 
atas kelompok rata-rata. Hal ini menunjukkan bahwa jumlah siswa yang memperoleh skor di atas kelompok rata-rata yaitu 302 responden atau sebesar $44,412 \%$. Sebaliknya, jumlah siswa yang memperoleh skor di bawah kelompok rata-rata yaitu 229 reponden atau sebesar $33,6767 \%$. Artinya, jumlah siswa yang mempunyai skor hasil belajar di atas rata-rata relatif banyak jika dibandingkan dengan siswa yang mempunyai skor di bawah kelompok rata-rata ataupun jika dibandingkan dengan kelompok rata-rata, dengan demikian dapat dikatakan bahwa sebagian besar responden memiliki skor hasil belajar relatif tinggi. Hal ini akan nampak lebih jelas pada penyebaran distribusi secara visual pada gambar histogram berikut ini.

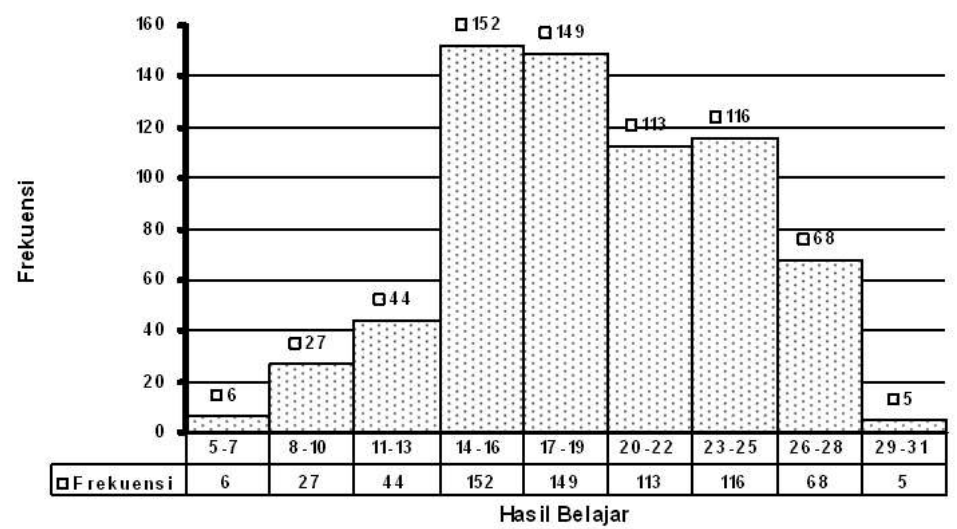

Gambar 1.

Histogram Data Mentah Variabel Hasil Belajar Siswa

\section{Skor Efektivitas Pemanfaatan Siaran TVE dengan Responden Siswa}

Untuk menyusun distribusi frekuensi dari perolehan skor efektifitas pemanfaatan siaran TVE dapat dilakukan antara lain dengan menggunakan aturan Sturges. Dari skor data variabel efektifitas pemanfaatan siaran TVE diperoleh skor minimum yaitu 108 , sedangkan skor maksimum 257 , sehingga rentang skor hasil belajar siswa adalah 149 . 
Dengan menggunakan aturan Sturges dan dengan jumlah responden 680, maka diperoleh banyak kelas interval 10 (hasil pembulatan ke atas), sedangkan panjang kelas interval 15 (hasil pembulatan berdasarkan syarat yaitu, p.i ${ }^{3} R+1$ ). Distribusi interval kelas, freukensi absolut, frekuensi relatif, dan frekuensi kumulatif skor efektifitas pemanfaatan siaran TVE disajikan pada tabel 2. berikut ini.

Tabel 2: Distribusi Interval Kelas, Frekuensi Absolut, Frekuensi Relatif, dan Frekuensi Kumulatif Skor Efektivitas Pemanfaatan Siaran TVE.

\begin{tabular}{|c|c|c|c|c|}
\hline No. & Interval Kelas & $\begin{array}{c}\text { Frekuensi } \\
\text { Absolut }\end{array}$ & $\begin{array}{c}\text { Frekuensi } \\
\text { Relatif Naik } \\
\text { dalam (\%) }\end{array}$ & $\begin{array}{c}\text { Frekuensi } \\
\text { Kumulatif } \\
\text { dalam (\%) }\end{array}$ \\
\hline \hline 1 & $108-122$ & 1 & 0,15 & 0,15 \\
\hline 2 & $123-137$ & 10 & 1,47 & 1,62 \\
\hline 3 & $138-152$ & 33 & 4,85 & 6,47 \\
\hline 4 & $153-167$ & 36 & 5,30 & 11,77 \\
\hline 5 & $168-182$ & 80 & 11,76 & 23,53 \\
\hline 6 & $183-197$ & 139 & 20,44 & 43,97 \\
\hline 7 & $198-212$ & 150 & 22,06 & 66,03 \\
\hline 8 & $213-227$ & 118 & 17,35 & 83,38 \\
\hline 9 & $228-242$ & 74 & 10,88 & 94,26 \\
\hline 10 & $243-257$ & 39 & 5,74 & 100 \\
\hline & Jumlah & 680 & 100,00 & \\
\hline
\end{tabular}

Dari distribusi frekuensi di atas dapat diketahui bahwa 150 $(22,06 \%)$ responden berada pada kelompok rata-rata, sedangkan $299(43,97 \%)$ responden berada di bawah kelompok rata-rata, dan $231(33,97 \%)$ responden berada di atas kelompok rata-rata. Hal ini menunjukkan bahwa jumlah siswa yang memperoleh skor di bawah kelompok rata-rata yaitu 299 responden atau sebesar 43,97\%. Sebaliknya jumlah siswa yang memperoleh skor diatas kelompok rata-rata yaitu 231 atau sebesar $33,97 \%$. 
Artinya jumlah siswa yang mempunyai skor efektivitas pemanfaatan TVE dibawah rata-rata relatif banyak jika dibandingkan dengan siswa yang mempunyai skor di atas kelompok rata-rata ataupun jika dibandingkan dengan kelompok rata-rata. Semakin tinggi skor perolehan pada variabel efektivitas pemanfaatan siaran TVE mengindikasikan bahwa responsen telah memanfaatkan siaran TVE secara optimal. Dengan demikian dapat dikatakan sebagian besar responden belum memanfaatkan siaran TVE secara efektif. Hal ini akan nampak lebih jelas pada penyebaran distribusi secara visual pada gambar histogram berikut ini.

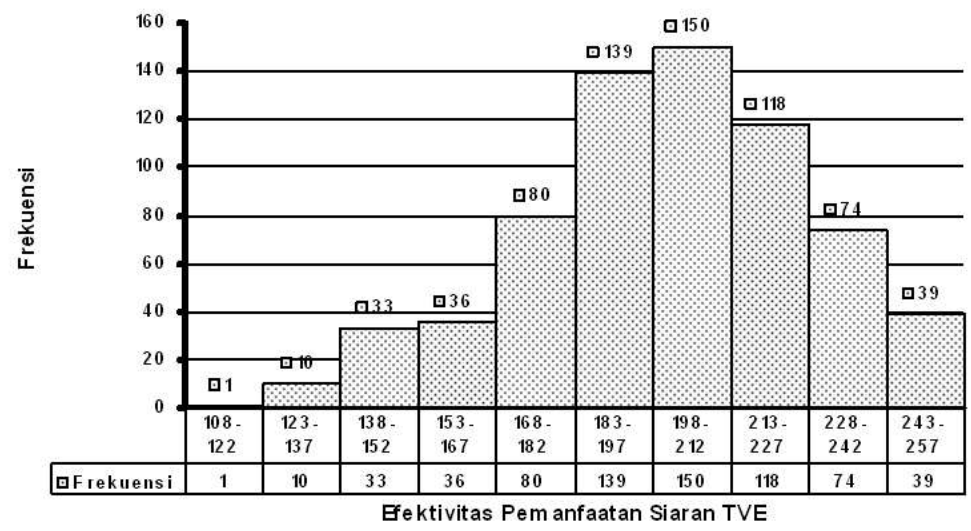

Gambar 2.

Histogram Data Mentah Variabel Efektivitas Pemanfaatan Siaran TVE

\section{Skor Efektivitas Pemanfaatan Siaran TVE dengan Responden Guru}

Dari skor data variabel efektifitas pemanfaatan siaran TVE diperoleh skor minimum yaitu 116 , sedangkan skor maksimum 297, sehingga rentang skor hasil belajar siswa adalah 181. Dengan menggunakan aturan Sturges dan dengan jumlah responden 649, maka diperoleh banyak kelas interval 10 (hasil pembulatan keatas), sedangkan panjang kelas interval 15 (hasil pembulatan berdasarkan syarat yaitu, $p \cdot i^{3} R+1$ ). Distribusi interval kelas, freukensi absolut, frekuensi relatif, dan frekuensi kumulatif 
skor efektifitas pemanfaatan siaran TVE disajikan pada tabel 3. berikut ini.

Tabel 3: Distribusi Interval Kelas, Frekuensi Absolut, Frekuensi Relatif, dan Frekuensi Kumulatif Skor efektifitas pemanfaatan siaran TVE.

\begin{tabular}{|c|c|c|c|c|}
\hline No. & Interval Kelas & $\begin{array}{c}\text { Frekuensi } \\
\text { Absolut }\end{array}$ & $\begin{array}{c}\text { Frekuensi } \\
\text { Relatif Naik } \\
\text { dalam (\%) }\end{array}$ & $\begin{array}{l}\text { Frekuensi } \\
\text { Kumulatif } \\
\text { dalam (\%) }\end{array}$ \\
\hline 1 & $115-132$ & 5 & 0,763 & 0,763 \\
\hline 2 & $133-150$ & 16 & 2,443 & 3,206 \\
\hline 3 & $151-168$ & 23 & 3,511 & 6,718 \\
\hline 4 & $169-186$ & 25 & 3,817 & 10,534 \\
\hline 5 & $187-204$ & 49 & 7,481 & 18,015 \\
\hline 6 & $205-222$ & 96 & 14,656 & 32,672 \\
\hline 7 & $223-240$ & 144 & 21,985 & 54,656 \\
\hline 8 & $241-258$ & 167 & 25,496 & 80,153 \\
\hline 9 & $259-276$ & 112 & 17,099 & 97,252 \\
\hline 10 & $277-294$ & 17 & 2,595 & 99,847 \\
\hline 11 & $295-312$ & 1 & 0,153 & 100,000 \\
\hline \multicolumn{2}{|r|}{ Jumlah } & 655 & 100,00 & \\
\hline
\end{tabular}

Dari distribusi frekuensi di atas dapat diamati bahwa 144 $(21,985 \%)$ responden berada pada kelompok rata-rata, sedangkan $214(32,672 \%)$ responden berada di bawah kelompok rata-rata, dan 297 (45,343\%) responden berada diatas kelompok rata-rata. Hal ini menunjukkan bahwa jumlah guru yang memperoleh skor diatas kelompok rata-rata yaitu 297 responden atau sebesar $45,343 \%$, sebaliknya jumlah guru yang memperoleh skor dibawah kelompok rata-rata yaitu 214 atau sebesar $32,672 \%$. Artinya jumlah guru yang mempunyai skor efektivitas pemanfaatan TVE diatas rata-rata relatif banyak jika dibandingkan dengan guru yang mempunyai skor di bawah kelompok rata-rata ataupun jika dibandingkan dengan kelompok rata-rata. 
Semakin tinggi skor perolehan pada variabel efektivitas pemanfaatan siaran TVE mengindikasikan bahwa responsen telah memanfaatkan siaran TVE secara optimal. Dengan demikian dapat dikatakan sebagian besar responden telah memanfaatkan siaran TVE cukup efektif. Hal ini akan nampak lebih jelas pada penyebaran distribusi secara visual pada gambar histogram berikut ini.

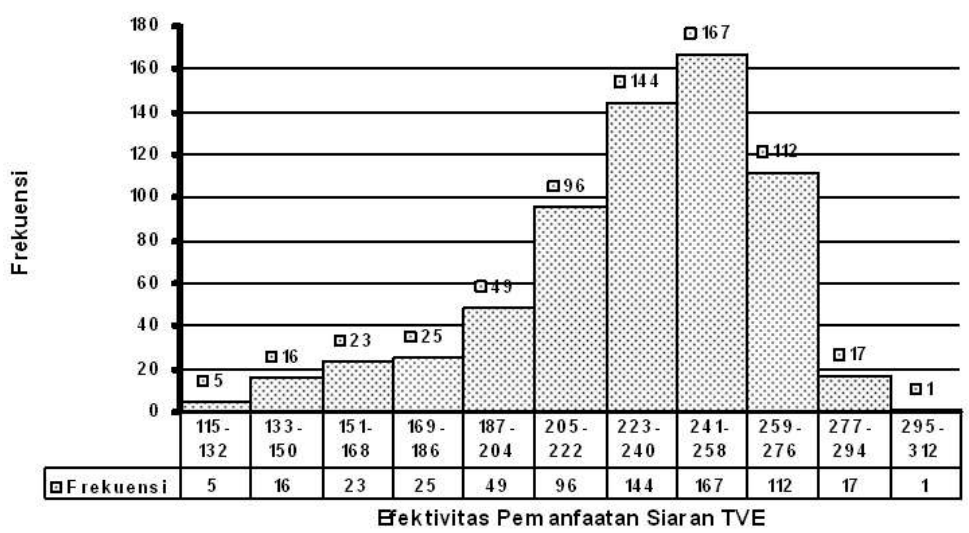

Gambar 3. Histogram Data Mentah Variabel Efektivitas Pemanfaatan Siaran TVE

\section{KONTRIBUSI SIARAN TVE TERHADAP PENUNTASAN WAJAR DIKDAS 9 TAHUN}

Terdapat hubungan positif antara efektivitas pemanfaatan siaran TVE (X) dengan Hasil belajar siswa (Y), hal ini ditunjukkan oleh hasil perhitungan analisis regresi sederhana untuk variabel hasil belajar siswa $(Y)$ atas variabel efektivitas pemanfaatan siaran TVE (X) diperoleh persamaan regresi $v=-5,69+0,124 \mathrm{X}$. Hasil perhitungan uji signifikansi dan linearitas regresi disajikan pada tabel-4 berikut ini. 
Tabel 4: Anava Uji Signifikansi dan Linearitas Regresi $Y$ atas $X$ dengan Persamaan: $v=-5,69+0,124 X$

\begin{tabular}{|l|c|c|c|c|c|c|}
\hline \multicolumn{1}{|c|}{$\begin{array}{c}\text { Sumber } \\
\text { Variansi }\end{array}$} & dk & JK & RJK & \multirow{2}{*}{ F $_{\text {hitung }}$} & \multicolumn{2}{|c|}{$F_{\text {tabel }}$} \\
\cline { 6 - 8 } & & & & $\alpha=0,05$ & $\alpha=0,01$ \\
\hline Total & 680 & 263150 & & & & \\
\hline Regresi a & 1 & 246697,2059 & $\begin{array}{c}246697,205 \\
9\end{array}$ & & & \\
\hline Regresi b/a & 1 & 7718,228 & 7718,228 & $\begin{array}{c}599,13 \\
*\end{array}$ & 3,856 & \multirow{2}{*}{6,692} \\
\hline Sisa & 678 & 8734,266 & 12,882 & & & \\
\hline Tuna cocok & 117 & 2411,555 & 20,612 & $1,829^{*}$ & 1,263 & 1,392 \\
\hline Galat & 561 & 6322,711 & 11,270 & & & \\
\hline
\end{tabular}

Keterangan:

* $\quad=$ regresi signifikan $\left(F_{\text {hitung }}=599,13>F_{\text {tabel }}=3,855\right)$

$\mathrm{s} \quad=$ signifikan, linear $\left(\mathrm{F}_{\text {hitung }}=1,829>\mathrm{F}_{\text {tabel }}=1,263\right)$

$\mathrm{dk}=$ derajat kebebasan

$\mathrm{JK}=$ jumlah kuadrat

RJK = rerata jumlah kuadrat

$\mathrm{F}_{\mathrm{h}}=\mathrm{F}_{\text {hitung }}$

$\mathrm{F}_{\mathrm{t}}=\mathrm{F}_{\text {tabel }}$

Berdasarkan pada uji signifikansi dan uji linearitas tersebut, dapatlah disimpulkan bahwa persamaan regresi $v=-5,59+0,124 \mathrm{X}$ signifikansi dan linier, hal ini berarti setiap peningkatan satu unit skor efektivitas pemanfaatan siaran TVE pada konstanta $-5,69$ menghasilkan 0,124 peningkatan hasil belajar siswa. Hubungan antara efektivitas pemanfaatan siaran TVE dan hasil belajar siswa ini akan nampak lebih jelas secara visual pada persamaan regresi $v=-5,69+0,124 X$ gambar berikut ini. 


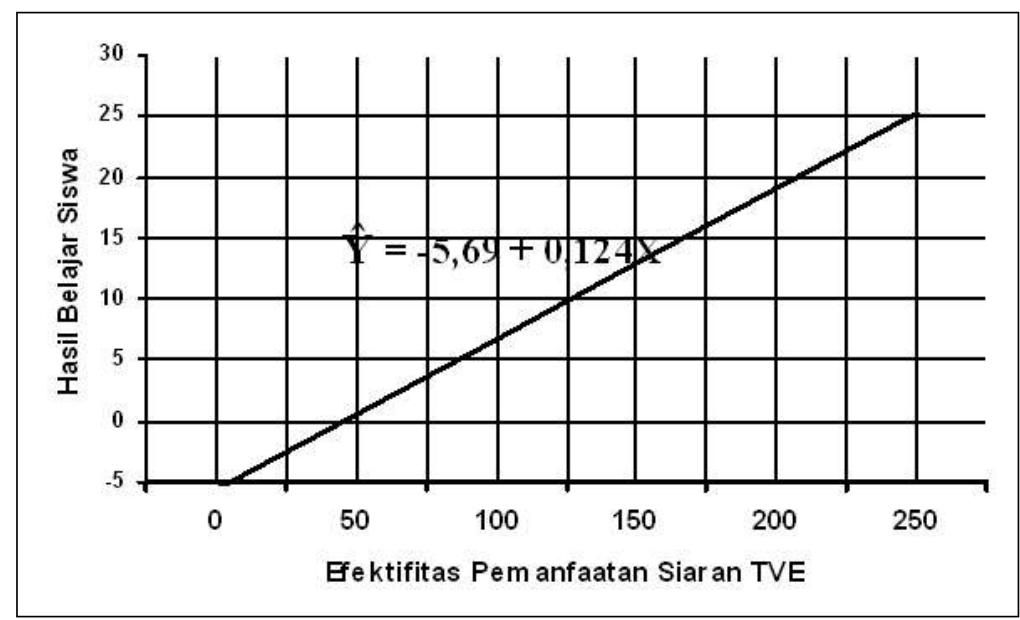

Gambar 4. Grafik Persamaan regresi: $v=-5,69+0,124 X$

Persamaan regresi: $v=5,651+0,124 X$ signifikan dan linier, hal ini berarti setiap kenaikan satu unit skor efektivitas pemanfaatan siaran TVE, maka hasil belajar siswa akan naik 0,124 pada konstanta 5,69

Kekuatan hubungan antara efektivitas pemanfaatan siaran TVE dengan hasil belajar siswa berdasarkan uji signifikansi koefisien korelasi ditunjukkan oleh korelasi $r=0,685$. Dengan perkataan lain terdapat hubungan positif antara efektivitas pemanfaatan siaran TVE dengan hasil belajar siswa. Jadi semakin tinggi skor efektivitas pemanfaatan siaran TVE efektivitas pemanfaatan siaran TVE, maka semakin tinggi skor hasil belajar siswa. Sebaliknya semakin rendah skor efektivitas pemanfaatan siaran TVE, maka semakin rendah skor hasil belajar siswa.

Sedangkan koefisien determinasi yang merupakan kuadrat dari koefisien korelasi antara efektivitas pemanfaatan siaran TVE dengan hasil belajar siswa diperoleh sebesar $r^{2}=0,4692$. Hal ini 
memberikan informasi tentang kontribusi dari masing-masing variabel diatas, yaitu menginformasikan bahwa $46,92 \%$ hasil belajar siswa ditentukan oleh variasi efektivitas pemanfaatan siaran TVE. Hasil perhitungan uji signifikansi hubungan antara efektivitas pemanfaatan siaran TVE dengan hasil belajar siswa disajikan pada tabel 5 berikut ini.

Tabel 5: Uji Signifikansi Hubungan antara Efektivitas Pemanfaatan Siaran TVE dengan Hasil Belajar Siswa

\begin{tabular}{|c|c|c|c|c|c|c|}
\hline Korelasi & $\mathbf{n}$ & $\mathbf{r}$ & $\mathbf{r}^{2}$ & $\mathbf{t}_{\text {hitung }}$ & \multicolumn{2}{|c|}{$\mathbf{t}_{\text {tabel }}$} \\
\cline { 5 - 7 } & & & & & $(0,05)$ & $(0,01)$ \\
\hline \hline Y dengan $X$ & 680 & 0,685 & 0,4692 & $24,48^{*}$ & 1,645 & 2,33 \\
\hline
\end{tabular}

\section{BESARNYA PENINGKATAN KUALITAS YANG AKAN DICAPAI SISWA}

Dari hasil analisis dapat dibuktikan bahwa efektivitas pemanfaatan siaran TVE mempunyai hubungan "positif" dengan hasil belajar siswa di Sekolah perintisan yang tersebar di 28 propinsi.

Kekuatan hubungan antara efektivitas pemanfaatan siaran TVE dengan hasil belajar siswa berdasarkan uji signifikansi koefisien korelasi ditunjukkan oleh korelasi $r=0,685$ dengan persamaan regresi $v=-5,69+0,124 X$, hal ini berarti setiap peningkatan satu unit skor efektivitas pemanfaatan siaran TVE pada konstanta $-5,69$, menghasilkan 0,124 peningkatan hasil belajar siswa atau dengan perkataan lain semakin tinggi efektivitas pemanfaatan siaran TVE, maka semakin tinggi skor hasil belajar siswa, sebaliknya semakin rendah efektivitas pemanfaatan siaran TVE, maka semakin rendah skor hasil belajar siswa. 


\section{KONTRIBUSI PUSTEKKOM DALAM MENDORONG KEBERHASILAN PENUNTASAN WAJAR DIKDAS 9 TAHUN}

Televisi Edukasi (TVE) tidak dapat dilepaskan dari pembicaraan tentang Pusat Teknologi Informasi dan Komunikasi Pendidikan (Pustekkom) Departemen Pendidikan Nasional (Depdiknas) yang menjadi bidan kelahirannya. Pustekkom merupakan sebuah pusat di bawah pembinaan Sekretariat Jenderal Depdiknas yang mempunyai pengabdian di bidang rekayasa teknologi informasi dan komunikasi pendidikan. Penyelenggaraaan siaran TVE membantu memperluas akses dan peningkatan mutu pendidikan.

TVE juga tidak dapat dilepaskan dari Penuntasan Wajib Belajar Pendidikan Dasar 9 Tahun. Hal ini dikarenakan Program TVE diperioritaskan pada pendidikan dasar 9 tahun. Penuntasan Wajib Belajar Pendidikan Dasar 9 Tahun ditargetkan selesai pada tahun 2008/2009. Indikator utama penuntasan Wajar Dikdas adalah pencapaian Angka Partisipasi Kasar (APK) SMP secara nasional mencapai $95 \%$ pada tahun $2008 / 2009$.

Dengan demikian penyelenggaraan siaran TVE tidak secara langsung dapat dihubungkan dengan penuntasan wajib belajar Pendidikan Dasar 9 Tahun. Kontribusi siaran TVE berkaitan dengan hal-hal yang bersifat kualitas bukan kuantitas, sedangkan Penuntasan Wajar Dikdas 9 Tahun berkaitan dengan hal-hal yang bersifat kuantitas. Sehingga kontribusi siaran TVE terhadap Penuntasan Wajar Dikdas 9 Tahun.

\section{PENUTUP}

Penelitian merupakan suatu proses yang panjang, berawal dari minat untuk mengetahui fenomena tentang efektivitas pemanfaatan siaran TVE kemudian berkembang menjadi gagasan, penentuan populasi dan penarikan sampel, pemilihan metoda penelitian, menyusun definisi konseptual dan operasional berdasarkan sintesis teori, penyusunan instrumen penelitian, uji validasi penilai, dan 
analisis data berdasarkan masing-masing variabel serta hubungan antara variabel melalui analisis statistik.

Meskipun berbagai tahap yang harus ditempuh hingga diperoleh hasil penelitian yang memenuhi kaidah-kaidah ilmiah/prosedur metoda ilmiah, namun tidak terlepas dari berbagai kekurangan dan kelemahan sebagai akibat keterbatasan penelitian. Keterbatasan penelitian tersebut merupakan salah satu faktor yang tidak dapat dihindarkan atau dikendalikan.

Dimungkinkan adanya jawaban siswa dalam kuesioner tersebut yang tidak sesuai dengan keadaan sebenarnya atau dengan kata lain siswa tidak memberikan jawaban yang sesuai dengan kondisi yang sesungguhnya. Hal tersebut tentu saja kurang dapat menggambarkan efektivitas pemanfaatan siaran TVE yang sesungguhnya, karena dimungkinkan siswa memberikan jawaban yang tidak mengindikasikan bahwa ia (siswa) sebenarnya telah melaksanakan kegiatan pembelajaran melalui media siaran TVE. Demikian juga dengan siswa yang memberikan jawaban yang mengindikasikan efektivitas pemanfaatan yang tinggi, meskipun ia (siswa) tidak menggunakan pemanfaatan siaran TVE secara optimal.

\section{DAFTAR PUSTAKA}

Fred N. Kerlinger. Asas-Asas Penelitian Behavioral, diterjemahkan oleh Landung R Simatupang. Yogyakarta: Universitaas Gadjah Mada. 1990.

Jhon Howard., Doing Job Better. http://www.Mng.Djbet.com.2001. 2001.

M. Kathyn Barto. and Martin C.David., Management. New York:McGraw Hill.Inc. 1991.

Peter F. Drucker, Management Task Responsibilities Practices, London:William Heinemann Ltd. 1994.

Soekidjo Notoatmojo, Metodologi Penelitian Kesehatan, Jakarta: Penerbit Rineka Cipta. 2002. 
Sugiyono. Statistik Nonparametris: Untuk Penelitian. Bandung: CV Alfabeta. 2001.

Sudjana, Metoda Statistika. Bandung: Tarsito. 1996.

Robert M. Kaplan, Basic Statistic For The Behavioral Sciences.

London: Allyn and Bacon Inc., 1987. 